\title{
An intronic polymorphism of the gene Plakophilin-3 is associated with IVF failure
}

\author{
Mohamad Sami Joha ${ }^{1 *}$, Chadi Soukkarieh², Marwan Alhalabi ${ }^{3,4}$
}

\author{
${ }^{1}$ Department of Biochemistry and Microbiology, Faculty of Pharmacy, Aleppo University, Aleppo, Syria \\ ${ }^{2}$ Department of Biology, Faculty of Sciences, Damascus University, Damascus, Syria \\ ${ }^{3}$ Division of Reproductive Medicine, Embryology and Genetics, Faculty of Medicine, Damascus University, \\ Damascus, Syria \\ ${ }^{4}$ Assisted Reproduction Unit, Orient Hospital, Damascus, Syria
}

Received: 16 May 2019

Accepted: 01 July 2019

\section{*Correspondence:}

Dr. Mohamad Sami Joha,

E-mail: samihematology@gmail.com

Copyright: () the author(s), publisher and licensee Medip Academy. This is an open-access article distributed under the terms of the Creative Commons Attribution Non-Commercial License, which permits unrestricted non-commercial use, distribution, and reproduction in any medium, provided the original work is properly cited.

\section{ABSTRACT}

Background: Implantation failure is determined when transferred embryos fail to implant following in vitro fertilization (IVF). In recent years, many studies suggest that implantation failure could be related to several genetic factors. In the current study, authors aimed to investigate the association of PKP3 rs10902158 (G>A) polymorphisms with the risk of implantation failure after ICSI treatment.

Methods: 97 women, who underwent ICSI treatment owing to male factor infertility, were prospectively recruited in this cross-sectional study. Genomic DNA was prepared from peripheral blood samples in order to analyze the polymorphism (rs10902158) at the PKP3 gene by PCR-RFLP. The Results were presented as a genotype (GG, GA, and AA), and their relationship to IVF outcome was analyzed.

Results: The patients were divided into two groups according to clinical pregnancy: the pregnant group included 51 patients $(53 \%)$ and the non-pregnant group included 46 patients $(47 \%)$. The clinical pregnancy outcome was significantly different between genotypes, which was $0 \%, 45.8 \%$ and $58.8 \%$ in the patients having the genotype AA, GA and GG respectively ( $\mathrm{p}$-value $=0.03$ ).

Conclusions: The presence of the allele A of the PKP3 SNP rs10902158 is associated with a reduced clinical pregnancy outcome in the patients undergoing ICSI treatment and may be helpful predictor for implantation failure.

Keywords: Implantation failure, In-vitro fertilization, Plakophilin-3, SNP

\section{INTRODUCTION}

Implantation failure was one of the most common causes of unsuccessful pregnancy in women undergoing in vitro fertilization (IVF) or intra- cytoplasmic sperm injection (ICSI) which are the most common assisted reproductive technology (ART) treatments. Despite advances that have been made since the introduction of these techniques, implantation of the embryo is still the most important rate-limiting step: even high-quality embryos frequently fail to implant resulting in an implantation rate of approximately $25-30 \%$ per transferred embryo. ${ }^{1}$ Implantation failure (IF) refers to when an implanted embryo fails to result in the development of an intrauterine gestational sac following embryo transfer (ET), as determined by ultrasonography. ${ }^{2}$ Several causes of IF have been reported, including embryo, uterine and immunological factors, as well as thrombophilic 
conditions, however, the genetic mechanisms underlying IF remain not completely understood. ${ }^{2}$

Embryo implantation is a multifactorial event that depends on the interaction of the blastocyst with the receptive endometrium and consists of molecular signaling by the embryo, followed by apposition and attachment to the endometrium. ${ }^{3}$ Following the formation of the fetal-maternal interface, the essential second step involves the invasion of the embryo through the endometrium. $^{4}$

Recently, several genetic-association studies have revealed associations between the IF risk and certain genetic polymorphisms, including tumor suppressor protein p53, cyclooxygenase-2 (COX-2), methylenetetrahydrofolate reductase (MTHFR), plasminogen activator inhibitor-1, vascular endothelial growth factor, and leukocyte antigen-G. ${ }^{3-9}$

The architecture and integrity of epithelial cells is mediated by several types of cell-cell junctions, including adherent junctions, desmosomes, tight junctions, and gap junctions. ${ }^{10}$

Desmosomes are adhering junctions that are involved in cell-cell adhesion, differentiation, and signal transduction. ${ }^{11,12}$ They are responsible for strong intercellular adhesion and are as such indispensable in tissues that undergo mechanical stress. ${ }^{13}$ Desmosomal adhesion was also shown to be involved in epithelial morphogenesis to an extent comparable to the role of adherent junctions. ${ }^{14}$ They are composed of 3 zones: extracellular core region, outer and inner dense plaque. Desmosomal cadherins (desmogleins, desmocollins) extend into extracellular core and outer dense plaque, while their cytoplasmic tails connect to plakoglobin, Plakophilins and desmoplakin. Desmoplakin associates to keratin intermediate filaments within inner dense plaque to establish connection between intermediate filaments and plasma membrane..$^{15,16}$

Mature desmosomes are characterized by being calcium independent, also known as "hyperadhesion" of desmosomes. ${ }^{17-19}$

Loss of tissue integrity due to failure of desmosomal adhesive function is considered a major underlying cause of inherited, auto- immune, and bacterial toxin-mediated disorders. ${ }^{20-22}$

Plakophilins are structural proteins and therefore part of cytoplasmic plaques of desmosomes. They are considered to be important in connecting other desmosomal proteins, but also for attachment of intermediate filaments to desmosomes, which makes them important for stability and adhesion of cells and tissues. ${ }^{23}$ They are members of the p120ctn family of armadillo- related proteins important for intercellular interactions and cytoskeletal maintenance. ${ }^{10,24}$ Armadillo proteins are characterized by a series of repeated motifs of about 45 amino acids called arm repeats. Members of the p120ctn family share a characteristic organization of their arm repeat domain which suggests an ancient evolutionary relationship. ${ }^{25}$ They can also exert signaling functions by generating and transducing signals that affect transcription, posttranscription regulation and translation. ${ }^{24-26}$

Plakophilin-3 (PKP3) belongs to the Plakophilin family. It is described as beta-catenin and armadillo protein of the desmosomal plaque, which is synthesized in simple and stratified epithelia, present in cytoplasm, membrane and nucleus. ${ }^{27,28}$ However, it also has important nonjunctional functions, such as regulating protein synthesis, growth control, and transcription. ${ }^{29-31}$ There is a growing interest about Plakophilin-3 functions and functional interactions at the cellular and molecular levels, particularly, in cancer initiation and progression. ${ }^{10,23}$

The importance of cell-cell junction proteins in placentation and implantation biology is known. ${ }^{32}$ Although many studies indicate that alterations of intercellular adhesion may be associated with implantation failure, no study has investigated if the dysregulation or genetic polymorphisms of Plakophilins are associated with IF. ${ }^{32-34}$

Our objective is to evaluate the association between the SNP rs10902158 of the PKP3 gene and the risk of IF after ICSI treatment. To our knowledge, no studies based on Plakophilin-3 polymorphism or expression and its correlation to fetal implantation have yet been published.

\section{METHODS}

A total of 97 women, who underwent ICSI treatment owing to male factor infertility, were prospectively recruited in this cross-sectional study from $1^{\text {st }}$ October 2017 to $1^{\text {st }}$ April 2018, at Assisted Reproduction Unit at Orient Hospital, Syria. All Participants gave informed consent, according to the protocol approved by the local Ethics Committee at Damascus University and Health Ministry.

\section{Inclusion criteria}

- Patients age less than 38 years, with good ovarian reserve (normal basal FSH, AMH), having normal gynecological, hormonal and anatomical state, and at least two good quality embryos were easily transferred.

\section{Exclusion criteria}

- Women with known immunological disease (APS, LAC, ACL, ATA) or thrombophilia (protein S or C deficiency, Factor V Leiden, hyperhomocysteinemia etc.), Women with pelvic pathology: Fibroids, Adenomyosis, Endometriosis, Polyps, Septum, 
Hydrosalpinx) and when endometrium thickness was $<7$ before ultrasound guided embryo transfer (ET).

All patients were on long protocol using GnRH agonist. Ovulation induction was by HMG or rFSH and the dose was adjusted according to response and when 3 leading follicles reached $17-18 \mathrm{~mm}, 10000 \mathrm{IU}$ of $\mathrm{HCG}$ was given, and oocytes retrieval was scheduled 35 hours later.

Ultrasound guided embryo transfer (ET) of 2-3 embryo was performed in cleavage stage (day 3). Luteal phase support was achieved with vaginal micronized progesterone gel (9\%) once daily. Clinical pregnancy (presence of gestational sac in ultrasound) was done after 3 weeks post ET. The patients were divided into two groups according to clinical pregnancy: the pregnant group and the non-pregnant group.

\section{Molecular genotyping}

\section{DNA extraction}

Blood samples were obtained on the day of oocytes retrieval prior to the procedure. The leukocyte genome was extracted using the Genomic DNA Isolation Kit (GeneDireX, Malaysia) according to the manufacturer's instructions and was stored at $-20 \mathrm{C}^{0}$ until use.

\section{PCR amplification for PCR-RFLP}

The genomic region of the PKP3 gene (intron 1) that contains the SNP rs10902158: G>A, was amplified by PCR with the following primers: forward primer, 5'TGCAACAGGGCATACTGGTC-3'; and reverse primer, 5'-CCTGGGCTCACCTGTGTC-3'. Primers were synthesized by Eurofins Genomics (Ebersberg, Germany). PCR amplification was carried out using 1X OnePCR reaction mixture (GeneDireX, Malaysia) and $150 \mathrm{nM}$ of each primer. The PCR amplification was performed in a GeneAmp PCR System 9700 (Applied Biosystems, USA). Samples were incubated for $5 \mathrm{~min}$ at $94^{\circ} \mathrm{C}$ to denature the target DNA followed by 45 cycles at $94^{\circ} \mathrm{C}$ for $30 \mathrm{~s}, 59^{\circ} \mathrm{C}$ for $50 \mathrm{~s}$ and $72^{\circ} \mathrm{C}$ for $30 \mathrm{~s}$ and finally for 7 min extension at $72{ }^{\circ} \mathrm{C}$. An amplicon of $650 \mathrm{bp}$ was expected.

\section{Restriction digest of the amplified DNA}

Aliquots of $18 \mu \mathrm{L}$ of each $650 \mathrm{bp}$ amplified product were digested with the restriction enzyme Sau96I (Thermo Fisher Scientific, USA) as recommended by the manufacturer.

\section{Electrophoresis}

Electrophoresis of digested fragments was carried out on $2.5 \%$ agarose gel stained with ethidium bromide, and presence of fragments was visualized by UV transilluminator. Fragment sizes were assessed against a 100 bp DNA ladder (GeneDireX, Malaysia).

\section{Statistical analysis}

For the analysis of the data, Pearson chi-square and continuity correction chi-square tests have been used. For all analyses, a value of less than 0.05 was considered statistically significant. SPSS Software (version 25) was used for the analysis.

\section{RESULTS}

\section{Infertility investigation}

To confirm the male factor infertility, a routine infertility investigation was done in all women (serum FSH, LH, PRL, E2, TSH, AMH concentrations) and it detected no sign of perturbation. In addition, the statistical analysis by Pearson Chi-square test between the previous parameters and the genotype of the PKP3 SNP rs10902158 was showed no significant statistical difference. There was also no significant difference in age between patients according to the genotype (Table 1).

Table 1: Characteristics of patients according to the genotype (the values represent mean $\pm \mathrm{SD}$ ).

\begin{tabular}{|lllll|}
\hline \multirow{2}{*}{ Parameter } & Genotypes & & P-value $^{*}$ \\
\hline Age $($ years $)$ & AA $(\mathbf{n = 5})$ & GA $(\mathbf{n = 2 4})$ & GG (n=68) & 0.82 \\
\hline FSH $(\mathrm{mIU} / \mathrm{ml})$ & $31.8 \pm 3.27$ & $29.92 \pm 4.09$ & $30.13 \pm 4.51$ & 0.26 \\
\hline LH $(\mathrm{mIU} / \mathrm{ml})$ & $7.41 \pm 3.68$ & $6.42 \pm 1.65$ & $6.99 \pm 1.86$ & 0.95 \\
\hline PRL $(\mathrm{ng} / \mathrm{ml})$ & $1.99 \pm 0.65$ & $1.66 \pm 1.08$ & $2.01 \pm 1.03$ & 0.72 \\
\hline E2 $(\mathrm{pg} / \mathrm{ml})$ & $20.45 \pm 2.54$ & $22.18 \pm 16.13$ & $15.61 \pm 9.27$ & 0.69 \\
\hline TSH $(\mu \mathrm{IU} / \mathrm{ml})$ & $51.52 \pm 72.32$ & $22.4 \pm 13.09$ & $24.01 \pm 13.51$ & 0.81 \\
\hline AMH $(\mathrm{ng} / \mathrm{ml})$ & $1.59 \pm 0.36$ & $2.70 \pm 0.90$ & $2.46 \pm 1.24$ & 0.84 \\
\hline
\end{tabular}

*Pearson Chi-square.

The patients were divided into two groups according to clinical pregnancy: the pregnant group included 51 patients $(53 \%)$ and the non-pregnant group included 46 patients $(47 \%)$. 


\section{The relation between IVF outcome and the PKP3 SNP rs10902158.}

The clinical pregnancy outcome was significantly different between the genotypes, where the women carrying the A allele have an obvious reduction in clinical pregnancy outcome than women with the $G$ allele with a p-value of 0.03 as calculated by Pearson Chi-square test (Table 2).
Table 2: The clinical pregnancy outcome according to the genotype.

\begin{tabular}{|c|c|c|c|c|}
\hline \multirow[t]{2}{*}{ IVF outcome } & \multicolumn{4}{|c|}{ Genotypes } \\
\hline & $\mathbf{A A}$ & GA & GG & \\
\hline Non-pregnant (n) & 5 & 13 & 28 & \\
\hline Pregnant (n) & 0 & 11 & 40 & \\
\hline $\begin{array}{l}\text { Clinical pregnancy rate } \\
(\%)\end{array}$ & 0 & 45.8 & 58.8 & $P=0.03^{*}$ \\
\hline
\end{tabular}

*Pearson Chi-square.

Table 3: The IVF outcome parameters according to the genotype (the values represent $\operatorname{mean} \pm \mathrm{SD}$ ).

\begin{tabular}{|lllll|}
\hline The IVF outcome parameter & Genotypes & \multicolumn{3}{c|}{ P-value $^{*}$} \\
\hline Oocyte $(\mathrm{n})$ & $\mathbf{A A}(\mathbf{n = 5})$ & $\mathbf{G A}(\mathbf{n = 2 4})$ & GG $(\mathbf{n = 6 8})$ & 0.04 \\
\hline MII (n) & $10.40 \pm 8.99$ & $13.75 \pm 5.68$ & $12.99 \pm 6.7$ & 0.08 \\
\hline Fertilization $(\mathrm{n})$ & $6.20 \pm 5.36$ & $7.96 \pm 3.90$ & $8.57 \pm 5.20$ & 0.24 \\
\hline Embryos (n) & $6.00 \pm 5.24$ & $6.04 \pm 3.71$ & $5.84 \pm 4.20$ & 0.05 \\
\hline
\end{tabular}

*Pearson Chi-square.

While the number of oocytes and embryos $(\mathrm{p}=0.04$ and $\mathrm{p}=0.05$, respectively) were significantly affected by the presence of the A allele, the number of MII oocytes and the number of fertilization were not affected as shown in (Table 3).

\section{DISCUSSION}

The techniques of assisted reproduction have developed to circumvent human infertility. However, a high rate of implantation failure was recorded in these techniques. ${ }^{2}$ Among the many causes evaluated, the single nucleotide polymorphism (SNP) in different genes was growly described. ${ }^{5-7}$ The SNP may affect gene expression, RNA stability, and protein function and therefore may cause disease. ${ }^{35}$

Desmosomal cell adhesion is indispensable for folliculogenesis and normal embryonic development. ${ }^{32}$ PKP3 is a novel important integrator of desmosomes junction and it has important non-junctional functions. $^{24,25}$ The intronic SNP rs10902158 of the PKP3 gene have recently related to the risk of death in HIV disease and tuberculosis. ${ }^{36,37}$ In this study, we examined the potential association of this SNP and the risk of IF after ICSI treatment.

Our results showed that no influence of the PKP3 SNP rs10902158 on the hormonal characteristics of patients indicating that PKP3 do not have an effect on hormones that influence or predict the IVF outcome.

Interestingly, our data found that all women who carried the genotype AA had implantation failure (IF). The carrying of allele A was also significantly associated with decrease in oocyte numbers, embryo numbers, and clinical pregnancy rate (CRP). These findings suggest that a functional variant in the $P K P 3$ gene may influence the folliculogenesis and the early stage of embryo development.

A recent study demonstrated that a polymorphism in the first intron affected the transcription activity of the gene. ${ }^{38}$ Similarly, this may be suggested for the PKP3 gene where the site of the SNP rs10902158 is in the first intron. Therefore the allele A of this SNP could influence intron removal or affect the enhancer activity and hence PKP3 protein quantity, so destabilizing the desmosomes integrity.

In addition, the defect of PKP3 production may also alter the molecular mechanisms of implantation. Because PKP3 regulate the inflammation, one of the possible mechanisms is the influence of PKP3 on the inflammatory reaction that is mediated by the embryo implantation. ${ }^{39,40}$

According to this hypothesis, a polymorphism in COX-2, a key enzyme in inflammation, was associated with increased risk of implantation failure. ${ }^{6}$

\section{CONCLUSION}

The present study is the first study, which indicates that the presence of the allele A of the PKP3 SNP rs 10902158 is associated with a reduced clinical pregnancy outcome in the patients undergoing ICSI treatment.

This variant may also constitute a helpful biomarker to predict the implantation failure. More studies are needed for both parents to demonstrate this hypothesis and to elucidate the precise molecular mechanism of PKP3 in folliculogenesis and embryo development. 


\section{ACKNOWLEDGMENTS}

Authors would like to appreciate the collaboration of the patients and express gratitude to Dr. Khalid Baghdadi, Mr. Mhd Nabil Serri Charif, Dr. Adnan Alkhatib and Dr. Nawras Alhalabi for their kind collaboration.

Funding: The Study was funded by a grant from the scientific research committee of Damascus University Conflict of interest: None declared

Ethical approval: The study was approved by the Institutional Ethics Committee

\section{REFERENCES}

1. Vélez MP, Connolly MP, Kadoch IJ, Phillips S, Bissonnette F. Universal coverage of IVF pays off. Hum Reprod. 2014;29:1313-9.

2. Coughlan C, Ledger W, Wang Q, Liu F, Demirol A, Gurgan $\mathrm{T}$, et al. Recurrent implantation failure: definition and management. Reprod Biomed Online. 2014;28:14-38.

3. Valdes CT, Schutt A, Simon C. Implantation failure of endometrial origin: it is not pathology, but our failure to synchronize the developing embryo with a receptive endometrium. Fertil Steril. 2017;108:15-8.

4. Wei P, Yu FQ, Chen XL, Tao SX, Han CS, Liu YX. VEGF, bFGF and their receptors at the fetal-maternal interface of the rhesus monkey. Placenta. 2004;25:184-96.

5. Feng Y, Wu YY, Lin XJ, Yang L, Luo ZJ, Zhou YH, et al. Associations between the codon 72 polymorphism of the TP53 gene and the risk of recurrent implantation failure. J Obstet Gynaecol Res. 2016;42:184-9.

6. Salazar LA, Inostroza M, Jara C, Vega F, García R, Ciuffardi I, et al. Association of $-765 \mathrm{G}>\mathrm{C}$ polymorphism of the COX-2 gene with recurrent embryo implantation failure in Southern Chilean women. Clin Chim Acta. 2010;411:1822-4.

7. Luo L, Li DH, Li XP, Zhang SC, Yan CF, Wu JF, et al. Polymorphisms in the nuclear factor kappa B gene association with recurrent embryo implantation failure. Genet Mol Res. 2016;15:1-7.

8. Jung YW, Kim JO, Rah H, Kim JH, Kim YR, Lee Y, et al. Genetic variants of vascular endothelial growth factor are associated with recurrent implantationfailure in Korean women. Reprod Biomed Online. 2016;32:190-6.

9. Nardi Fda S, Slowik R, Wowk PF, da Silva JS, Gelmini GF, Michelon TF, et al. Analysis of HLA-G polymorphisms in couples with implantation failure. Am J Reprod Immunol. 2012;68:507-14.

10. Schwarz J, Ayim A, Schmidt A, Jäger S, Koch S, Baumann R, et al. Differential expression of desmosomal plakophilins in various types of carcinomas: correlation with cell type and differentiation. Human Pathol. 2006;37:613-22.
11. Suzuki KG. New insights into the organization of plasma membrane and its role in signal transduction. Int Rev Cell Mol Biol. 2015;317:67-96.

12. Green KJ, Gaudry CA. Are desmosomes more than tethers for intermediate filaments?. Nat Rev Mol Cell Biol. 2000;1:208-16.

13. McGrath JA, McMillan JR, Shemanko CS, Runswick SK, Leigh IM, Lane EB, et al. Mutations in the plakophilin 1 gene result in ectodermal dysplasia/skin fragility syndrome. Nat Genet. 1997;17:240-4.

14. Runswick SK, O'Hare MJ, Jones L, Streuli CH, Garrod DR. Desmosomal adhesion regulates epithelial morphogenesis and cell positioning. Nat Cell Biol. 2001;3:823-30.

15. Delva E, Tucker DK, Kowalczyk AP. The desmosome. Cold Spring Harb Perspect Biol. 2009;1:1-17.

16. Gerull B, Heuser A, Wichter T, Paul M, Basson CT, McDermott DA, et al. Mutations in the desmosomal protein plakophilin-2 are common in arrhythmogenic right ventricular cardiomyopathy. Nat Genet. 2004;36:1162-4.

17. Desai BV, Harmon RM, Green KJ. Desmosomes at a glance. J Cell Sci. 2009;122:4401-7.

18. Garrod D. Desmosomes in vivo. Dermatol Res Pract. 2010;2010:1-17.

19. Stokes DL. Desmosomes from a structural perspective. Curr Opin Cell Biol. 2007;19:565-71.

20. Amagai M, Stanley JR. Desmoglein as a target in skin disease and beyond. J Invest Dermatol. 2012;132:776-84.

21. Campuzano O, Alcalde M, Allegue C, Iglesias A, García-Pavía P, Partemi S, et al. Genetics of arrhythmogenic right ventricular cardiomyopathy. J Med Genet. 2013;50:280-9.

22. Kitajima Y. New insights into desmosome regulation and pemphigus blistering as a desmosomeremodeling disease. Kaohsiung $\mathbf{J}$ Med Sci. 2013;29:1-13.

23. Demirag GG, Sullu Y, Gurgenyatagi D, Okumus NO, Yucel I. Expression of plakophilins (PKP1, PKP2, and PKP3) in gastric cancers. Diagn Pathol. 2011;6:1-5.

24. Bass-Zubek AE, Godsel LM, Delmar M, Green KJ. Plakophilins: multifunctional scaffolds for adhesion and signaling. Curr Opin Cell Biol. 2009;2:708-16.

25. Hatzfeld M. Plakophilins: Multifunctional proteins or just regulators of desmosomal adhesion?. Biochim Biophys Acta. 2007;1773:69-77.

26. Wolf A, Krause-Gruszczynska M, Birkenmeier O, Ostareck-Lederer A, Hüttelmaier S, Hatzfeld $M$. Plakophilin 1 stimulates translation by promoting eIF4A1 activity. J Cell Biol. 2010;188:463-71.

27. Kundu ST, Gosavi P, Khapare N, Patel R, Hosing AS, Maru GB, et al. Plakophilin3 downregulation leads to a decrease in cell adhesion and promotes metastasis. Int J Cancer. 2008;123:2303-14. 
28. Schmidt A, Jäger S. Plakophilins-hard work in the desmosome, recreation in the nucleus?. Eur J Cell Biol. 2005;84:189-204.

29. Hofmann I, Casella M, Schnölzer M, Schlechter T, Spring H, Franke WW. Identification of the junctional plaque protein plakophilin 3 in cytoplasmic particles containing RNA-binding proteins and the recruitment of plakophilins 1 and 3 to stress granules. Mol Biol Cell. 2006;17:1388-98.

30. Yang C, Ströbel P, Marx A, Hofmann I. Plakophilinassociated RNA-binding proteins in prostate cancer and their implications in tumor progression and metastasis. Virchows Arch. 2013;463:379-90.

31. Fischer-Kešo R, Breuninger S, Hofmann S, Henn M, Röhrig T, Ströbel P, et al. Plakophilins 1 and 3 bind to FXR1 and thereby influence the mRNA stability of desmosomal proteins. Mol Cell Biol. 2014;34:4244-56.

32. Singh H, Aplin JD. Adhesion molecules in endometrial epithelium: tissue integrity and embryo implantation. J Anat. 2009;215:3-13.

33. Cakmak H1, Taylor HS. Implantation failure: molecular mechanisms and clinical treatment. Hum Reprod Update. 2011;17:242-53.

34. Timeva T, Shterev A, Kyurkchiev S. Recurrent implantation failure: the role of the endometrium. J Reprod Infertil. 2014;15:173-83.

35. Shastry BS. SNPs: impact on gene function and phenotype, in Single Nucleotide Polymorphisms. Methods Mol Biol. 2009;578:3-22.
36. Horne DJ, Randhawa AK, Chau TT, Bang ND, Yen NT, Farrar JJ, et al. Common polymorphisms in the PKP3-SIGIRR-TMEM16J gene region are associated with susceptibility to tuberculosis. J Infect Dis. 2012;205:586-94.

37. Gupta A, Montepiedra G, Gupte A, Zeldow B, Jubulis J, Detrick B, et al. Low vitamin-D levels combined with PKP3-SIGIRR-TMEM16J host variants is associated with tuberculosis and death in HIV-infected and-exposed infants. PLoS One. 2016;11:e0148649.

38. Tsukada S, Tanaka Y, Maegawa H, Kashiwagi A, Kawamori R, Maeda S. Intronic polymorphisms within TFAP2B regulate transcriptional activity and affect adipocytokine gene expression in differentiated adipocytes. Mol Endocrinol. 2006;20:1104-11.

39. Sklyarova T, van Hengel J, Van Wonterghem E, Libert C, van Roy F, Vandenbroucke RE. Hematopoietic plakophilin-3 regulates acute tissue-specific and systemic inflammation in mice. Eur J Immunol. 2015;45:2898-910.

40. Kim SM, Kim JS. A Review of mechanisms of implantation. Dev Reprod. 2017;21:351-9.

Cite this article as: Joha MS, Soukkarieh C,

Alhalabi M. An intronic polymorphism of the gene

Plakophilin-3 is associated with IVF failure. Int $\mathbf{J}$

Reprod Contracept Obstet Gynecol 2019;8:3092-7. 